\title{
FOMO syndrome and degeneration of written language in elementary school students
}

\section{E1 sindrome del FOMO y la degeneración del lenguaje escrito en los estudiantes de educación básica}

\author{
Marisol Yana Salluca ${ }^{1, a}$ \\ https://orcid.org/0000-0001-7223-1201
}

Wilson Gregorio Sucari Turpo
https://orcid.org/0000-0001-5874-0966

Hector Adco Valeriano ${ }^{2, c}$

https://orcid.org/0000-0001-5642-6164

Rebeca Alanoca Gutierrez, d

https://orcid.org/0000-0003-1795-7549

\author{
Nancy Yana Salluca ${ }^{3, e}$ \\ https://orcid.org/0000-0001-7589-9469
}

${ }^{1}$ Universidad Nacional del Altiplano, Puno, Perú

${ }^{2}$ Unidad de Gestión Educativa Local San Román,Puno, Perú

${ }^{3}$ Unidad de Gestión Educativa Local Azángaro, Puno, Perú

${ }^{a}$ myana@unap.edu.pe

b wsucari@unap.edu.pe

cnibelci27@gmail.com

dralanoca@unap.edu.pe

e nancyana2008@hotmail.com

\section{ABSTRACT}

The research was aim to determine the degree of relationship between syndrome FOMO (Fear of missing out) and written language students of Secondary Educational Institution "José Antonio Encinas" of Juliaca city, 2017. They used the descriptivecorrelational design of such non-experimental, positivist paradigm and approach quantitative. The sample was intentional and not probabilistic, made up of students from the fifth grade of secondary, the which they were evaluated with instruments: the questionnaire Fear of missing out syndrome to measure syndrome Fear of missing out and a second questionnaire to measure written language. At the end of the investigation it was identified that the students present Fear of missing out syndrome, very frequently at a very high level, with a frequency that represents $41.37 \%$. Likewise, it has been identified that $63 \%$ of students do not respect the spelling regulations, all evidenced in the level of use of the written language Chat. The results indicate that there is $\mathrm{r}=0.89^{* *}$, of correlation between the two variables, which implies a high positive relationship between Fear of missing out syndrome and written language.

Keywords: written language, normative, spelling, FoMO syndrome.

\author{
Recibido e1: 10/02/2019 \\ Aceptado e1: 17/10/2019
}

\section{RESUMEN}

La investigación tuvo como objetivo determinar el grado de relación entre el síndrome de Fear of missing out y el lenguaje escrito en estudiantes de la Institución Educativa Secundaria "José Antonio Encinas" de Juliaca, 2017. Se utilizó el diseño descriptivo-correlacional, de tipo no experimental, paradigma positivista y enfoque cuantitativo. La muestra ha sido intencional y no probabilística, conformada por estudiantes del quinto grado de secundaria, los que fueron evaluados con los instrumentos: el cuestionario de síndrome de Fear of missing out para medir el síndrome de Fear of missing out y un segundo cuestionario para medir el lenguaje escrito. Al término de la investigación se identificó que los estudiantes presentan síndrome de Fear of missing out, muy frecuentemente en un nivel muy alto, con una frecuencia que representa al $41.37 \%$. Asimismo, se ha identificado que el $63 \%$ de estudiantes no respetan la normativa ortográfica, todo ello evidenciado en el nivel de uso del lenguaje escrito Chat. Los resultados indican que existe $\mathrm{r}=0,89^{* *}$, de correlación entre las dos variables, el cual implica una relación positiva alta entre el síndrome de Fear of missing out y el lenguaje escrito.

Palabras Clave: lenguaje escrito, normativa, ortografía, síndrome de FoMO. 


\section{INTRODUCTION}

Currently social networks are a boom that has been bombarding the academic activity of students. They are easily inserted through a syndrome called FOMO - Fear of missing out, which is sometimes a terrifying anxiety where one is losing something absolutely fantastic, that feeling that others are having a wonderful experience and gratifying that we are not part of (Bosker, 2011; Gregory \& Rutledge, 2016; Gregory \& Rutledge, 2016).

The position of communication through social networks in our society is impressive, so it is that, the human being is establishing new forms of communication that are not even taught or regulated (Forero, 2011), learning from the world and adapting to various social media (Escobar, 2009). Just as the use of the Chat language, which not only makes them active subjects of learning, but also enables free expression, giving them a leading role in the circulation of virtual material (Morduchowicz, 2005), until losing control, is why It is urgent to promote new ways of learning online (Castillejos, Torres, \& Lagunes, 2016).

Empirical evidence on the relationship of FOMO syndrome and written language exists in small amounts. From them, Rocha's (2004) works on "The language of young people in chat" state that through chat you read what you want to read, not what you are trying to say. Better yet, the interlocutors say what they want to say, but they understand what they want and can understand.

Herrera, Pacheco, Palomar, and Zavala (2010) argue that adolescents addicted to Facebook are more prone to depression, to be less assertive, to have less quality of relationships with friends and family or to have more difficulty speaking in public than non-addicts. On the other hand, Samaniego (2003) states that natural human languages are diasystems and are subject to factors of temporal evolution, geographical diversity, sociocultural differentiation and dissimilar styles according to specific communication situations; however, the risk consists in disobedience or degeneration of traditional written language.

Likewise, Sánchez \& Sánchez (2010) indicate that, given the circumstances of the chat, in this case for academic purposes, users, despite their level of training, do not escape "miss" of spelling and typographical order, so that it is It is necessary to establish a series of guidelines and strategies that allow the strengthening of the communication skills involved in virtual communication. And do not allow distortions in the structure and functionality of words, which at the same time can explain that the spelling presents so many alterations (Gianmmatteo \& Albano, 2009).

These alterations are demonstrated in students when they communicate through expressive signs such as vocative, interjections, diminutive, emoticons, tone. The spelling has been stripped of its normalizing function in order to gain expressiveness and creativity placed in the construction of the messages (Arias, Ramos, Núñez, \& Inga, 2018). It is necessary to address the importance of language and raise awareness of its proper use in different communicative situations.

The objective of the research was to establish the relationship between FOMO syndrome and the degeneration of written language in students of basic education in the city of Juliaca in view of the increased use of cyber channels. Then the review of the theoretical framework of the investigation is carried out. Likewise, the research methodology is indicated. Subsequently, the results are presented and analyzed in statistical tables and, finally, the conclusions are reached.

\section{THEORETICAL FRAMEWORK}

\section{FoMO syndrome}

The term FoMO was coined by Dan Herman, it is a syndrome that is related to the general psychological malaise (Przybylski, Murayama, Dehaan, \& Gladwell, 2013). Social networks are not an addiction, but they can be a catalyst for maladaptive use, become sources of stress and anxiety, damaging the person's health, enclosing him in a depression of sadness, melancholy and absence of happiness; In addition, true clinical depression is a mood disorder in which feelings of sadness, loss, anger or frustration interfere with daily life (Herrera, et al., 2010). Johansson and Götestam (2004) state that people who realized that their friends do things or do activities to which they have not been invited, experience anxiety and depression.

It should be remembered that missing out on some activities of which you have not been a part is physically inevitable (Ponce, Ponce, \& 
Hernández, 2014), in some cases, it even affects the development of academic abilities and performances, for example, in children It affects reading and math skills; in adolescents, they have trouble sleeping and perform poorly in school (Wolfson \& Carskadon, 1998); In those aged 13 to 19 who sleep less time they obtained the worst ratings (Papalia, 2009), because they are aware of any type of connection signal, messages, upload and view photos among others (Bernstein, Borchardt, \& Perwien, 1996 ) and thus obsessions or compulsions cause significant anxiety or distress, and interfere with the normal routine of the child (Fernández, 2009).

On the other hand, Young (1998) states that the student being obsessed with checking their accounts on the Internet shows the following characteristics: $a$.Deprive yourself of the dream to be connected to the Network. $b$. Neglect other important activities such as family contact, social relationships, study or health care. c. Receive complaints regarding excessive use of the Network. d.Think about the Network constantly, even when you are not connected to it, and feel excessively irritated when the connection fails or is very slow. e. Try to limit the connection time and lose track of time. $f$.Lying about the actual time you are connected. $g$.Isolate socially, be irritable and lower performance in studies. $h$.Feel euphoria when you are in front of the computer.

On the other hand, Knapp (2012) states that any good moment is broken by discovering that one of your colleagues is having a great time in something you did not know. Dan (2011) says that teenagers and young adults are more susceptible and unconscious of FoMO, but they do not try to mitigate it but rather fall into depression. In short, it is the students who spend more time connected to their social media accounts, who become more depressed due to FoMO (Pantic, Damjanovic, Todorovic, Topalovic, Bojovic and Ristic, 2012). Even Ponce et al. (2014) affirm that the inappropriate use of social networks would cause sequels that are very committed to the human system. Among the neurological and physiological sequels analyzed would be: tumors, cognitive conditions, electromagnetic hypersensitivity, genotoxicity, sleep disorders, immune system and DNA.

\section{Written language: Chat language}

Language is a social system that includes not only lexical and grammatical elements, but also a mechanism that mixes an infinite number of linguistic elements. Hence it is impossible to think of the language as a list of words (Fiorin, 1998). On the other hand, language is a diverse linguistic social convention tool, and the existence of these different linguistic systems makes subjects apprehend the world and reality in different ways, which allows us to include and adapt to different social media. through communication (Escobar, 2009). Because the world has evolved and continues to evolve and with it the language, which has variations and individuals adapt it to the communicative scenarios where the culture and identity of the group and the subject is reflected (Sucari, 2019).

Unfortunately, today written language is losing its seriousness in the application of linguistic regulations, with greater boom even in these times of modernity, times of the era of connectivity. The influence of this falls on students, mainly in their communication and information system such as: WhatsApp, Chat, Facebook, email, among others, leading to the death of written language. The linguistic flexibility of the human being to adapt to his environment is reflected in the syllogism referenced by Wittgenstein (2013).

Likewise, the spelling principles in the language include all forms of the visual presentation of the writing system as a whole and the forms of the individual characters such as upper and lower case letters of the same letter (Goodman and Goodman, 1993).

The communicative context, in turn, implies not only oral and written language, but other languages that, normally, are not taught to individuals because they are not within the norm, that is, of the general pattern of society (Forero, 2011). And the meaning of words is an elementary cell that cannot continue to decompose and that represents the most elementary form of the union between thought and word (Vigotsky, Carrasco, \& Austin, 2008). So it is so that for young people the use of social networks opens them up to new forms of communication, a kind of digital jargon, adopting a different language that undermines the 
regulations and the framework of the spelling rules of written language (Bakhtin, 2006), killing her at the regulatory level.

Additionally, the chat is born with the aim of recovering the pleasure of speaking, this is achieved through the continuous exchange of verbal and "oral" interactions (not in vain who would say that such person has "written" me such a thing in the chat, instead of saying that he has "told me"?) It is about being with someone without being by his side, of being by his side without being close and, therefore, of not being alone. Most of the time, conversations are spontaneous and informal. The aim is to strengthen personal links between the interlocutors (Blanco, 2002). Moreover, as mentioned before, the new type of writing, which we will call 'ideophonematic ', can constitute a symbol of youth, identity, freedom for young people (Mayans and Planells, 2002), a form of communication that allows them to the majority of young people aged 12 to 15 , interact with their friends (Varas, 2010).

On the other hand, regardless of whether young people are more or less aware of this fact, ideophonematic writing assumes the social purpose of discussing the standard or, in short, of rebelling against the established norm (Cassany, 2011). Language used on the Internet is attributed according to (Borreguero, 2002; Crystal, 2001) is that it is written as spoken, that meets the characteristics of oral and written languages, which is a mixed code, intermediate between both types of linguistic manifestation. It even creates prominence because it requires creativity and time, to give them the opportunity to be "content producers" (Vuanello, 2015), called chats, which are used for other purposes, the truth is that it is probably the type of text that is most away from formal writing.; the one that is considered closer to the oral, to the varieties spoken of the language (Cassany, 2011). For this reason, the chat genre has been considered a hybrid, confusing genre (Mayans and Planells, 2002), a genre that requires new ways of approaching the understanding of these communicative processes (Llorens \& Capdeferro, 2011).

\section{METHOD AND MATERIALS}

\section{Method}

It is used the design descriptive-correlational, framed in the kind of research is not experimental, positivist paradigm and in the approach quantitative.

\section{Population}

The study was conducted in the city of Juliaca, which is located in the northern part of the province of San Román, in the center of the department of Puno. The reference population totals 3104 students and the type of sample applied has been the non-probabilistic parametric sample represented by 597 students in the fifth grade of secondary school.

\section{Data collection technique}

It was used the technique of survey instrument as two questionnaires that were prepared was applied based on the theoretical underpinnings of Bosker, 2011; Dan, 2011; Johansson \& Götestam, 2004; Przybylski et al., (2013). The reliability of the instrument was evaluated by determining its internal consistency by means of the Cronbach's alpha coefficient, each dimension was evaluated separately: Vulnerability of minds and prone to depression ( $\alpha=0.86)$; Obsession of browsing and reviewing your accounts online $(\alpha=0.83)$; Phobia for running out of signal and without contact ( $\alpha$ $=0.81)$; Gray matter damage $(\alpha=0.73)$. These results demonstrate the consistency and acceptable reliability of the instrument to measure the variable FOMO syndrome. The second instrument was the questionnaire to measure the level of use of written language and Chat language" de Sánchez (2007), the dimensions evaluated were: communicative process, vocabulary, normative structure, structure and coherence of the text, finally the sentence structure. The statistical package IBM SPSS Statistics version 22.0 was used to process and analyze the information. 


\section{Procedure and data analysis}

Students were provided with questionnaires regarding the two study variables, the same ones that they voluntarily developed because they were anonymous. For the variable FoMO syndrome, the questionnaire consisted of 20 items. For each of the alternatives it was codified (in scales), where each level of scale is given a respective value, in addition to measure the frequency of FoMO syndrome was performed through the Likert scale, which allowed us to locate the results obtained between the scales: very frequently, frequently, occasionally, rarely and never. On the other hand, for data processing of the level of use of written language Chat and language formalized written questionnaire was applied with the scales yes and no, very poor (01-05), poor (06-10), Regular (11 -13), good (14-17) and excellent (18-20).

Pearson's correlations were calculated and multiple regression analysis was used to explain the correlation between FOMO syndrome and degeneration of written language. SPSS 21 was used to perform the statistical analyzes. Finally, frequency distribution tables, figures, analysis and interpretation and discussion were elaborated respectively.

\section{RESULTS AND DISCUSSION}

There is a high positive correlation between FoMO syndrome and formal written language and Chat in secondary students in the city of Juliaca, the details of which are observed in the following tables:

\section{Table 1}

Symptoms of FoMO syndrome in the students of HEI "José Antonio Encinas" of Juliaca in the academic year 2017

\begin{tabular}{lll}
\hline FoMO syndrome & fi & $\mathbf{\%}$ \\
\hline $\begin{array}{l}\text { Vulnerability of minds and prone to } \\
\text { depression }\end{array}$ & 52 & 8.71 \\
$\begin{array}{l}\text { Obsession of browsing and } \\
\text { reviewing your accounts online }\end{array}$ & 275 & 46.07 \\
$\begin{array}{l}\text { Phobia for running out of signal and } \\
\text { without contact }\end{array}$ & 209 & 35 \\
Gray matter damage & 61 & 10.22 \\
\hline TOTAL & $\mathbf{5 9 7}$ & $\mathbf{1 0 0}$ \\
\hline
\end{tabular}

Table 1 indicates the results regarding the level of FoMO syndrome presented by the students of HEI "José Antonio Encinas" of Juliaca. It is observed that the majority of students $(46.07 \%)$ are obsessed with browsing and checking their accounts online; $(35 \%)$ of students have a phobia of running out of signal and without contact; a total of $(10.22 \%)$ of students, consider presenting damages in the gray matter; Only $(8.71 \%)$ of students are vulnerable and prone to depression.

So, being a problem the misuse of social networks, students cannot control addiction and fear of losing contact. It is urgently necessary to promote new ways of learning online (Castillejos et al., 2016). Without denying ICTs, they are elements that also allow a permanent update and represent the possibility of designing and using new ways of organizing and accessing information, help cohesion and provide social support under their specific characteristics, which allows to obtain well-being and accompaniment for the netizens before the resolution of problems and in some cases to be cultured and to know what happens in their locality and in the rest of the world (Huamán, Palomino, Atarama, \& Castañeda, 2013). It even requires them creativity and time, to give them the opportunity to be "content producers" (Vuanello, 2015). However, being isolated from this activity they turn to worrying anxiety. Anxiety disorder of childhood and adolescence is separation anxiety disorder, in this case, being disconnected. Most cases of excessive anxiety disorder will now be included in generalized anxiety disorder, and avoidance disorder has been conceptualized as social phobia. The student is aware of any type of connection signal, messages, upload and view photos, among others present FoMO (Bernstein et al., 1996).

Bernstein et al. (1996) present results related to this research, they concluded that children with high levels of anxiety obtained low academic achievements, especially in reading and mathematics. The existence of anxious symptomatology in these children predicted the onset of anxiety in fifth grade; while, in this investigation, it is shown that $46.07 \%$ of students have high levels of obsession to browse and review their accounts online. The same who do not consider the spelling rules in the use of written language thus presenting a deficiency in communication.

Social networks are not negative or positive in the actions of the human being, everything depends on the responsibility with which they are used. For example, the use of control devices and networks 
has led to the development of pathologies such as: Technophilia, Cibercondr ed, Nom or fob $\mathrm{i}$ a, S índrome of the mouse, FoMO, etc. All of this indicates that inappropriate, stubborn and uncontrolled use of social networks is considered a pathology that must be treated (Almansa, Fonseca, \& Castillo, 2013; Ponce et al., 2014). However, damaging gray matter would directly affect the processing of information, that is, they do not use efficient reasoning and this can interfere with academic performance.

Facebook addicts are more prone to depression, to be less assertive, to have less quality of relationships with friends and family, or have more difficulty speaking in public than non- addicts (Herrera et al., 2010), contributions that match our results. On the other hand, they claim that Facebook addicts have a greater tendency to lower self-esteem. Therefore, they show a more devalued perception of their physique, of their self- concept and of their intellect, presenting problems in academics, placing the majority at the deficient level (Blakemore, Frith, \& Marina, 2007). Non-addicted subjects are more balanced and achieve greater control of themselves when faced with both internal and external stressors (Jiménez \& Pantoja, 2007). Finally, we agree with Blakemore et al., (2007), stating that the excessive use of these networks creates stress in students, affecting their learning.

\section{Table 2}

Level of use of formal written language and Chat language in the students of the IES "José Antonio Encinas" of Juliaca in the academic year 2017

\begin{tabular}{lllll}
\hline \multicolumn{1}{c}{ WRITTEN LANGUAGE } & CATEGORIES & FI & \multicolumn{1}{c}{$\%$} \\
\hline LANGUAGE & Communicative process & YES & 459 & 77 \\
FORMAL & & NO & 138 & 23 \\
& Vocabulary & YES & 242 & 41 \\
& Normative structure & NO & 355 & 59 \\
& & YES & 430 & 72 \\
& Structure and coherence of the text & NO & 167 & 28 \\
& & YES & 338 & 57 \\
& Sentence structure & NO & 259 & 43 \\
& & YES & 382 & 64 \\
& Subtotal & NO & 215 & 36 \\
\hline CHAT & Communicative process & YES & 270 & 45 \\
LANGUAGE & & NO & 327 & 55 \\
& vocabulary & YES & 357 & 60 \\
& & NO & 240 & 40 \\
& Normative structure & YES & 46 & 8 \\
& & NO & 551 & 92 \\
& Structure and coherence of the text & YES & 170 & 28 \\
& & NO & 427 & 72 \\
& Sentence structure & YES & 151 & 25 \\
& & NO & 446 & 75 \\
\cline { 2 - 5 } & Subtotal & & $\mathbf{1 0 0}$ \\
\hline TOTAL & & 597 & 100 \\
\hline
\end{tabular}

Table 2 shows the results obtained on the level of use of written language and Chat language by the students of the IES "José Antonio Encinas" of Juliaca. Where it is noted that in formal written texts $77 \%$ of students respect the communicative process with a formal language and 55\% do not respect the communicative process in the Chat language; $41 \%$ consider the appropriate use of vocabulary in formal language and $40 \%$ of students do not respect vocabulary in the Chat language; $72 \%$ of students respect the normative structure in the written language and $92 \%$ do not respect the normative structure in the Chat language; $57 \%$ write formal written language with coherence and $72 \%$ do not respect the coherence and structure of the text in the use of the Chat language; 64\% properly use the sentence structure; In written texts Chat, 55\% do not respect the communicative process, $40 \%$ of 
students do not respect the vocabulary used, $92 \%$ do not consider the normative structure of a text, $72 \%$ do not respect the coherence of a text and the $75 \%$ of students write without respecting the sentence structure.

Language is a tool of social convention, and the existence of these linguistic systems makes subjects apprehend the world and reality in different ways (Escobar, 2009). Therefore, we must understand that the world continues to evolve and with it the language, with its variations and considerations of use, that reflect the culture and identity of the group and the subject (Sucari, 2019). However, written language, in recent years, has deteriorated and this becomes more critical with the widespread use of social networks, causing linguistic flexibility in its use as an instrument of communication. Goodman and Goodman (1993) specify that there are spelling principles in the language that include all forms of the visual presentation of the writing system as a whole, such as the shapes of individual characters such as upper and lower case letters of the same letter, not Despite the daily use of written language in social networks, such as WhatsApp, Facebook or other technological communication possibilities, they have undermined this writing system with greater emphasis, generating a conflict in the limits that writing and orality allow despite to the existence of other languages that, normally, are not taught to individuals because they are not within the norm (Forero, 2011). In this sense, the meaning of words is susceptible to variations breaking the most elementary form of the union between thought and word (Vigotsky et al., 2008).

In this sense, the results found are related to those of Colombia and Spain, where the majority of young people between 12 and 15 years use social networks as a means that goes beyond socialization (Almansa et al., 2013; Varas , 2010), forgetting all formality, being completely absorbed by the power of technology, worried more about publishing something new or being centers of attention, inhibited to depend on a life of being aware of the events that occur, generating the FoMO syndrome in them.

On the other hand, Llorens \& Capdeferro (2011) affirm that social networks are tools for collaborative online learning, such as new frameworks for the development of interactions between actors in learning processes that require new ways of approaching the understanding of these. Therefore, it is the job of teachers to ensure that grammar rules of written language prevail in students, strengthen personal links between the interlocutors and use social networks as tools for personal and social development (Blanco, 2002). For this purpose, the ideophonematic writing used by young people is a symbol of youth, identity, freedom, freedom that does not consist in transgressing the norms of language (Mayans and Planells, 2002). Let's not allow it to interfere in the achievement of academic performances (Cusi \& Yana, 2017).

The results of the correlation between FoMO syndrome and written language show that the correlation coefficient is $\mathrm{r}=0.89$ from which it is assumed that, according to Pearson's correlation table, the degree of correlation is high and of direct type.

\section{CONCLUSIONS}

The relationship between FOMO syndrome and degeneration of written language in students is positive and high. In the tables presented, it is evident that students become obsessed with browsing and checking their accounts online, feel phobic for being left without a signal and without contact, have damage to gray matter and vulnerability of minds, and are prone to depression, that is, they have symptoms of FOMO syndrome.

Likewise, the degeneration of written language manifests itself when they do not consider the orthographic regulations in the communicative process, the vocabulary, the normative structure, the coherence of the text and the structure of the sentence in the communication between partners through social networks, that it is urgent to attend with innovative strategies that allow the proper and correct use of written language.

\section{GRATITUDE}

To the National del Altiplano University and to the Secondary Educational Institution "José Antonio Encinas" of Juliaca. Through its academic offices, it was allowed to reach and collect information and support the development of scientific knowledge.

\section{BIBLIOGRAPHIC REFERENCES}

Almansa, A., Fonseca, O., \& Castillo, A. (2013). Redes sociales y jóvenes. Uso de Face 
book en la juventud colombiana y española. Comunicar, 40(20), 127-135.

Arias, D., Ramos, T., Núñez, L., \& Inga, M. (2018). El ciberlenguaje juvenil universitario: Análisis de los textos de la página de Facebook "Confesiones". Propósitos y Representaciones, 6 (2), 339-405. Recuperado de doi: http://dx.doi.org/10.20511/pyr2018. v6n2.238

Bakhtin, M. (2006). Marxismo e filosofia da linguagem. São Paulo: Hucitec.

Bernstein, G., Borchardt, C., \& Perwien, A. (1996). Anxiety Disorders in Children and Adolescents: A Review of the Past 10 Years. Journal of the American Academy of Child \& Adolescent Psychiatry, 35(9), 11101119. https://doi.org/10.1097/00004583199609000-00008

Blakemore, S., Frith, U., \& Marina, J. (2007). Cómo aprende el cerebro: las claves para la educación. Barcelona:Ariel: Ariel.

Blanco, M. (2002). El chat: la conversación escrita. ELUA. Estudios de Lingüistica Universidad de Alicante, (16), 43-87. https:// doi.org/10.14198/ELUA2002.16.02

Borreguero, M. (2002). Entre oralidad y escritura: la lengua del correo electrónico y de los debates virtuales. En Congreso de Lingüística General (pp. 307-318). Cádiz: Area de Lingüística General.

Bosker, B. (2011). Fear of Missing Out. EE.UU. $y$ Reino Unido:SONAR JWT.Sonar JWT. Recuperado de http://www.campaignbrief. com/JWT FearOfMissingOut MarchReport. pdf

Cassany, D. (2011). En línia: llegir i escriure a la xarxa. (Vol. 183). Barcelona: Graó.

Castillejos, B., Torres, C., \& Lagunes, A. (2016). $\mathrm{La}$ seguridad en las competencias digitales de los millennials. Apertura. Revista de innovación educativa, 8(2), 54-69.

Crystal, D. (2001). Language and the Internet. New York: Cambridge University Press.

Cusi, L., \& Yana, M. (2017). El síndrome del FOMO y los desempeños académicos en la Facultad de Ciencias de la Educación de la Universidad Nacional del Altiplano. Revista de investigaciones de la escuela de Posgrado UNA Puno Perú, 6(3), 280-287. Recuperado de http://www.revistaepgunapuno.org/index. $\mathrm{php} /$ investigaciones/article/view/124/103

Dan, H. (2011). Fear of Missing Out, estrategia internacional de consultoría Ventajas competitivas firmes.EE. UU. y Reino Unido.
Recuperado de http://fomofearofmissingout. com/fomo.

Escobar, R. (2009). Los derechos humanos como prácticas discursivas. Diálogos de saberes, (31), 157-170.

Fernández, M. (2009). Los trastornos de ansiedad en niños y adolescentes: Particularidades de su presentación clínica. PSIMONART, 2(1), 93-101.

Fiorin, J. (1998). Linguagem e ideologia. São Paulo: Ática.: Ática.

Forero, N. (2011). Nominación como construcción de sujeto de derecho en la comunidad LGBT. Revista VIA IURIS, 10(10), 133-156.

Gianmmatteo, M., \& Albano, H. (2009). El español en internet: una mirada a su evolución en los fologs. Revista Digital Universitaria, 10 (3), 2-17. Recuperado de http://www.revista. unam.mx/vol.10/num3/art15/int15.htm

Goodman, Y., \& Goodman, K. (1993). Vygotsky desde la perspectiva del lenguaje total. Vygotsky y la educación, 263-292.

Gregory, E., \& Rutledge, P. (2016). Exploring Positive Psychology: The Science of Happiness and Well-Being: The Science of Happiness and Well-Being. Santa Barbara: Greenwood.: ABC-CLIO.

Herrera, M., Pacheco, M., Palomar, P., \& Zavala, D. (2010). La Adicción a FacebookRelacionada con la Baja Autoestima, la Depresión y la Falta de Habilidades Sociales. Psicología Iberoamericana, 18(1).

Huamán, F., Palomino, H., Atarama, T., \& Castañeda, L. (2013). Los escolares en la era digital: el consumo de medios de los alumnos de 5to de secundaria de los colegios públicos de la región Piura en Perú.Comuni@cción, $8(1), 16-25$.

Jiménez, A., \& Pantoja, V. (2007). Autoestima y Relaciones Interpersonales en Sujetos Adictos a Internet. Psicología - Segunda Época, XXVI (1), 78-89.

Johansson, A., \& Götestam, K. (2004). Internet addiction: Characteristics of a questionnaire and prevalence in Norwegian youth (12-18 years). Scandinavian Journal of Psychology, 45(3), 223-229. https://doi.org/10.1111/ j.1467-9450.2004.00398.x

Knapp,A. (2012).FOMO: Elmiedo a perderse algo (Fear of Missing Out) \&gt;\&gt; Consumidos \&gt;\&gt; Blogs EL PAÍS. Madrid.

Llorens, F., \& Capdeferro, N. (2011). Palabras clave Facebook's Potential for Collaborative e-Learning. Revista de Universidad y 
Sociedad del Conocimiento (RUSC), 8(2), 197-210.

Mayans i Planells, J. M. (2002). Género chat: cómo la etnografía puso un pie en el ciberespacio. Barcelona: Gedisa.: Asociación de Antropólogos Iberoamericanos en Red (AIBR).

Morduchowicz, R. (2005). Los adolescentes y las redes sociales: la construcción de la identidad juvenil en Internet. Buenos Aires: Nardacchione Gabriel.: Fondo de Cultura Económica, Buenos Aires. -Nardacchione Gabriel.

Pantic, I., Damjanovic, A., Todorovic, J., Topalovic, D., Bojovic-Jovic, D., Ristic, S., \& Pantic, S. (2012). Association between online social networking and depression in high school students: behavioral physiology viewpoint. Psychiatria Danubina, 24(1), 90-93.

Papalia, D. (2009). Psicología del desarrollo de la infancia a la adolescencia. MCGRAW-HILL / INTERAMERICANA DE MEXICO.

Ponce, E., Ponce, D., \& Hernández, M. (2014). Efectos neurológicos por teléfonos celulares: revisión bibliográfica y modelos matemáticos. Interciencia, 39(12), 843-849.

Przybylski, A. K., Murayama, K., Dehaan, C. R., \& Gladwell, V. (2013). Motivational, emotional, and behavioral correlates of fear of missing out. Computers in Human Behavior, 29(4), 1841-1848. https://doi.org/10.1016/j. chb.2013.02.014

Rocha, A. (2004). El lenguaje de los jóvenes en el Chat. Estudios sobre las Culturas Contemporáneas, 19(X), 109-140. Recuperado de http://www.redalyc.org:9081/ articulo.oa? id $=31601907$

Samaniego, J. (2003). Lenguaje y cibernética ¿es el lenguaje cibernético un riesgo para el idioma en la sociedad globalizada? Onomázein, 8, 257-260. Recuperado de http://www.redalyc. org/articulo.oa? id=134517976001

Sánchez, C. (2007). Lengua del Chat y registro formal de la lengua castellana en la escolaridad. Universidad de Chile. Recuperado de http://repositorio.uchile.cl/ handle/2250/106054

Sánchez, L., \& Sánchez, A. (2010). Usos académicos del chat y estrategias lingüísticas en la comunicación virtual sincrónica. Revista Virtual Universidad Católica del Norte, 30. Recuperado de http://revistavirtual.ucn.edu. co/, ISSN 0124-5821.

Sucari, W. (2019). Etimología y formación de palabras. ( $1^{\text {a }}$ edición). Puno Perú.

Varas, L. (2010). Imaginarios sociales que van naciendo en comunidades virtuales: facebook. En Crisis analógica, futuro digital: actas del IV Congreso Online del Observatorio para la Cibersociedad, celebrado del 12 al 29 de noviembre de 2009, 2010, ISBN 978-84-6137299-7 (p. 329).

Vigotsky, L., Carrasco, H., \& Austin, T. (2008). Pensamiento y lenguaje: teoría del desarrollo cultural de las funciones.

Vuanello, G. (2015). Los niños frente a Internet: seguridad, educación y tecnología. Trayectorias, 17(41).

Wittgenstein, L. (2013). Tractatus logicophilosophicus. Madrid: Tecnos.: Routledge.

Wolfson, A. R., \& Carskadon, M. A. (1998). Sleep schedules and daytime functioning in adolescents. Child development, 69(4), 875887.

Young, K.(1998). InternetAdiction:Theemergence of a new clinical disorder. CyberPsychology and Behavior, 1(3), 237-244. 